African Crop Science Journal by African Crop Science Society is licensed under a Creative Commons Attribution 3.0 Uganda License. Based on a work at www.ajol.info/ and www.bioline.org.br/cs DOI: http://dx.doi.org/10.4314/acsj.v24i1.4S

\title{
OPTIMISATION OF A SOMATIC EMBRYOGENESIS AND TRANSFORMATION PROTOCOL FOR FARMER-PREFERRED CASSAVA CULTIVARS IN KENYA
}

\author{
E.N. MARIGI, J.O. MASANGA ${ }^{1}$, T.L.MUNGA², L.S. KARANJA², M.P. NGUGI, W.M. THAGANA ${ }^{3}$, \\ D. $\mathrm{KIRUBI}^{3}$, M. MWANGI ${ }^{3}$, C.M. GITHUNGURI ${ }^{3}$, W.M. MUIRU ${ }^{4}$, D.W. MIANO ${ }^{4}$, A.E. ALAKONYA ${ }^{1}$ \\ and R.O. ODUOR \\ Plant Transformation Laboratory, Department of Biochemistry and Biotechnology, Kenyatta University, \\ P. O. Box 43844-00100, Nairobi, Kenya \\ ${ }^{1}$ Institute for Biotechnology Research, Jomo Kenyatta University of Agriculture and Technology, \\ P. O. Box 62000-00200, Nairobi, Kenya \\ ${ }^{2}$ Kenya Agricultural and Livestock Research Organization, P. O. Box 57811, Nairobi, Kenya \\ ${ }^{3}$ Department of Agricultural Science and Technology, Kenyatta University, P. O. Box 43844-00100, \\ Nairobi, Kenya \\ ${ }^{4}$ Department of Plant Science and Crop Protection, University of Nairobi, P. O. Box 29053-00625, \\ Nairobi, Kenya \\ Corresponding author: oduor.richard@ku.ac.ke
}

\begin{abstract}
Cassava (Manihot esculenta Crantz) is a major food crop in developing countries, and holds potential for industrial use. It is, however, affected by various biotic and abiotic stresses that greatly affect its production. The existing regeneration and transformation protocols are not compatible with all cassava cultivars, thus efficient and robust transformation and regeneration protocols for farmer-preferred cultivars need to be optimised for ease of transfer of novel genes. The objective of this study was to develop an efficient transformation and regeneration protocol for a farmer-preferred Kenyan cassava cultivar. We cultured immature leaf lobe and stem explants on Murashige and Skoog (MS) medium, supplemented with varying concentrations of 2,4-dichlorophenoxyacetic acid (2,4-D), Picloram and á-naphthalene acetic acid (NAA). Plants were recovered on media with 6Benzylaminopurine (BAP) and $\mathrm{GA}_{3}$ under a 16 hour light/8 hour darkness photoperiod regime. Results showed high regeneration and transformation frequencies for both cultivars. High frequencies of callus induction (>98\%) for both cultivars, were obtained when 2,4-D and Picloram were used. Similarly, both auxins initiated somatic embryogenesis, with Picloram producing the highest frequency of somatic embryos ( $>92 \%$ ) in TMS 60444, using stem explants. Gus assays revealed high frequencies of transformation of $>77 \%$ (TMS 60444) and $60 \%$ (Kibanda meno mkubwa). This protocol offers promising perspectives for rapid improvement of these cultivars and, therefore, provides a platform for cleaning planting materials, as well as cassava genetic improvement programmes such as control of viral diseases.
\end{abstract}

Key Words: Cytokinin, Manihot esculenta, regeneration protocol

\section{RÉSUMÉ}

Le manioc (Manihot esculenta Crantz) est une culture vivrière de grande importance pour les pays en développement, avec un potentiel pour l'usage industriel. Néanmoins, le manioc est sujet à des stress d'origines biotique et abiotique, affectant sa production. Les protocoles de régénération et de transformation existante ne sont pas compatibles avec toutes les accessions de manioc. Ainsi, il est nécessaire de développer des protocoles de régénération et de transformation efficaces pour les accessions adoptées par les paysans, afin de faciliter les transferts de gènes d'intérêt. L'objectif de cet etude était de développer un protocole de régénération et de 
transformation adapte a la variété de manioc. Des feuilles et tiges immatures ont été cultivées sur des media Murashige et Skoog (MS), auxquels différentes concentrations de 2,4-dichlorophenoxyacetic acide (2,4-D), Picloram et á-naphtalène acétique acide (NAA). Les plantes ont été recouvertes de 6-Benzylaminopurine (BAP) et GA3 sous une photopériode de $16 \mathrm{~h}$ jour/8h nuit. Les résultats ont montré des fréquences élevées de régénération et de transformation pour les deux cultivars Kibanda meno mkubwa et TMS 60444. Des fréquences élevées d'induction de callosités ( $>98 \%$ ) ont été obtenues pour les deux cultivars, lorsque 2,4-D et Picloram ont été utilisés. De la même façon, les deux embryogenèses somatiques initiées a l'auxine, avec des explants de tiges et du Picloram ont exhibe la fréquence la plus élevée d'embryon somatique (>92\%) en TMS 60444. Des essais de Gus ont révélés des fréquences élevées de transformation $>77 \%$ (TMS 60444) et 60\% (Kibanda meno mkubwa). Ce protocole offre des perspectives pour l'amélioration rapide de ces cultivars, et par conséquent, fournit une plateforme pour la production de matériels de culture propres, mais aussi servira d'outil dans les programmes d'amélioration génétique visant la lutte contre les maladies virales.

Mots Clés: Cytokinine, Manihot esculenta, protocole de génération

\section{INTRODUCTION}

Cassava (Manihot esculenta Crantz), a woody perennial shrub, is a vital food crop for over a billion people, especially in developing countries. Also, it holds potential for production of industrial starch and bioethanol (Chetty et al., 2013). Despite these values, the production and productivity of the crop is constrained by cyanogenic glycosides, post-harvest among other factors, pests and diseases (Legg and Raya, 1998; Fan et al., 2011). It is estimated that over 77,502 ha of land in Kenya are currently under cassava cultivation (FAO, 2011), yet the crop is threatened by two major diseases: cassava mosaic disease, caused by single stranded DNA geminiviruses; and the cassava brown streak disease, caused by a single stranded RNA ipomivirus (Chetty et al., 2013). Strategies to control these diseases have greatly relied upon conventional improvement programmes, which have encountered massive limitations (Ceballos et al., 2004).

Cassava improvement through conventional breeding, further remains a challenge due to poor seedset, inconsistent flowering and heterozygosity that hinder backcrossing (Opabode et al., 2013). Biotechnology, through genetic engineering, holds great potential for long-term improvement of crops for enhanced production towards food security. Recent reports of success in generation of disease-free plants, such as transgenic papaya against ringspot virus (Gonsalves, 1998) and CMD-free cassava (Vanderschuren et al., 2007) offer great promise towards other stresses not tried out so far. Cassava genetic engineering could allow rapid development of CMD and CBSD resistance, if efficient and robust transformation and regeneration technology for farmer-preferred cultivars is provided. This requires optimisation of existing protocols for ease of transfer of novel genes, since existing regeneration and transformation protocols may not be compatible with all the cultivars (Hankoua et al., 2006; Saelim et al., 2006; Elibariki et al., 2014).

Success in transformation and regeneration of cassava has been previously reported, with protocols employing different phytohormones and explants, including apical meristems, zygotic embryos, immature leaf lobes and stems (Medina et al., 2007; Fletcher et al., 2011; Rossin and Rey, 2011). While the majority of studies are biased towards use of immature leaf lobes as explants, their occurrence (immature leaf lobes) per parent stock is limited; hence, necessitating the possibility of exploring other plant parts such as stems.

This study aimed at regenerating Kenyan coastal cassava cultivars using different types of explants under the influence of a range of growth hormones.

\section{MATERIALS AND METHODS}

Plant materials. Cassava cultivar, Kibanda meno $m k u b w a$, from the Coastal Province of Kenya was selected for the study since it is preferred by farmers because of its high starch levels that enables it fetch high prices in the market 
(Mwango'mbe et al., 2013). For comparison, the model variety, TMS 60444, was used due to its wide use in tissue culture.

In vitro cultures. Parent stocks of the cultivar were obtained from Kenya Agricultural and Livestock Research Organisation (KARLO), Mtwapa, Mombasa, located in the coastal region of Kenya. Parent plants were propagated in a glasshouse at the Plant Transformation Laboratory at Kenyatta University. In vitro plantlets were established on a cassava micropropagation medium comprising $4.4 \mathrm{~g} \mathrm{l}^{-1}$ Murashige and Skoog (MS) salts with vitamins (Murashige and Skoog, 1962), $30 \mathrm{~g} \mathrm{l}^{-1}$ of sucrose and $8 \mathrm{~g} \mathrm{l}^{-1}$ phyto agar. Explants were then prepared by poking of immature leaf lobes (ILL) and longitudinal dissection for stems; and cultured on callus induction media. The media comprised of MS salts with Gamborg B5 vitamins, supplemented with varying concentrations of Picloram and 2,4-D, $100 \mathrm{mg} \mathrm{l}^{-1}$ myoinositol, $0.5 \mathrm{mg}$ $\mathrm{l}^{-1} \mathrm{CuSO}_{4}, 50 \mathrm{mg} \mathrm{l}^{-1}$ case in hydrolysate and $30 \mathrm{~g}$ $1^{-1}$ sucrose. Auxin concentrations were 4, 6, 8 and $10 \mathrm{mg} \mathrm{l}^{-1}$ and were added individually to the media prior to sterilisation, by autoclaving at $121^{\circ} \mathrm{C}$ for 15 minutes. To induce calli, ten explants were cultured per petri-plate, across the four treatments and the cultures incubated at $28{ }^{\circ} \mathrm{C}$ in a growth chamber. The lighting in the growth chamber followed a photoperiodic regime of 16 hours of light provided by fluorescent lamps $\left(100 \mathrm{mEs}^{-1}\right.$ $\mathrm{m}^{-2}$ ) and 8 hours of darkness.

For somatic embryogenesis, 30 calli (replicated 3 times) were transferred on a similar medium (as in callus induction experiments), and the cultures maintained there for 28 days. Emerging somatic embryos were matured on a medium comprising of MS salts with Gamborg vitamins, $30 \mathrm{~g} \mathrm{l}^{-1}$ sucrose, $8 \mathrm{~g} \mathrm{l}^{-1}$ agar and varying combination ratios of BAP, NAA and $\mathrm{GA}_{3}$ (Table 1). Germination and plantlet recovery were achieved on maturation media, supplemented with $0.8 \%$ w/v activated charcoal. Recovered plantlets were then rooted on a hormone-free MS medium, with $30 \mathrm{~g} \mathrm{l}^{-1}$ of sucrose and $8 \mathrm{~g} \mathrm{l}^{-1}$ phytoagar. These plantlets were later acclimatised on peat moss and hardened in the glasshouse in potted soil. Surviving plants were transferred to bigger pots with soil for subsequent evaluation.
Transformation. Transformability of the cassava cultivars in this study was assessed by cocultivating immature leaf lobes with Agrobacterium tumefaciens strain EHA 101, harboring binary vector PTF 102 (Fig. 1) (Frame et al., 2002). The vector contains a Gus reporter gene, driven by $35 \mathrm{~S}$ promoter and terminator. It also has the bar gene that confers resistance to the herbicide basta and, therefore, is used as the plant selectable marker for positively transformed tissues (Fig. 1). A total of ninety immature leaf lobe explants were co-cultivated with EHA 101 for generation of putative transformants,

TABLE 1. Phyto-hormone combination ratios used for somatic embryo maturation and germination of cotyledonary embryos

\begin{tabular}{llll}
\hline Media & \multicolumn{3}{c}{ Combination ratios $\left(\mathrm{mg} \mathrm{l}^{-1}\right)$} \\
\cline { 2 - 4 } & BAP & NAA & $\mathrm{GA}_{3}$ \\
\hline M & 3 & 0.02 & 0.5 \\
M1 & 3 & 0.01 & 1 \\
M2 & 2 & 0.03 & 0.5 \\
M3 & 2 & 0.01 & 1.5 \\
M4 & 1 & 0.02 & 1.5 \\
M5 & 1 & 0.03 & 1 \\
\hline
\end{tabular}

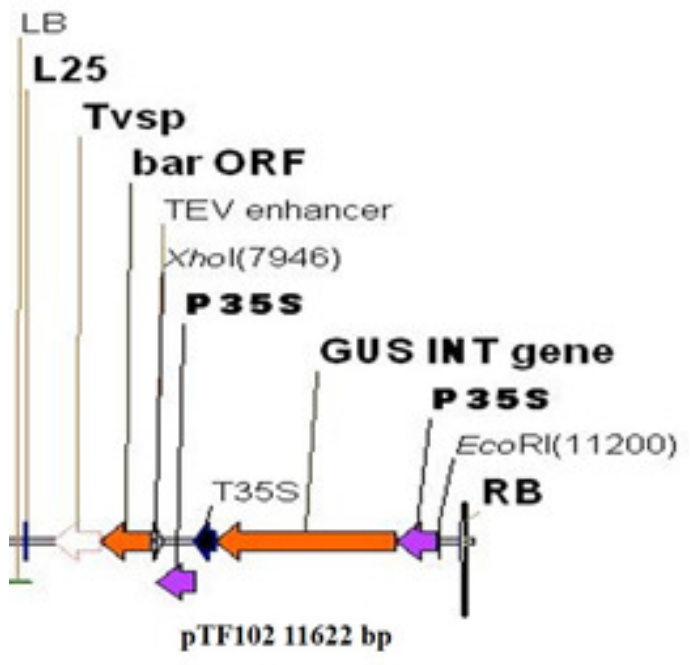

Figure 1. T-DNA region of standard binary vector pTF102. LB, Left border; RB, right border; bar, phosphinothricin acetyltransferase gene; gus-int, -glucuronidase gene containing an intron; P35S, CaMV 35S promoter; Tvsp, soybean vegetative storage protein terminator; T35S, CaMV 35S terminator. 
according to Chetty et al. (2013). Histochemical Gus assays were performed on ten putatively transformed calli (replicated 3 times), as described by Jefferson (1987).

Data collection and analyses. All callus induction experiments were performed using ten explants per plate and five plates per treatment, for both cultivars under study. Callus induction, somatic embryo and transformation frequencies were recorded. Callus induction frequency was calculated by counting the number of explants forming a callus, as a percentage of the total explants cultured. Somatic embryo frequency was calculated by taking the number of calli showing presence of somatic embryo, as a percentage of total calli. Transformation frequency was computed by taking the number of calli showing a blue colouration, as a percentage of total calli following Gus assay.

Data were analysed by Multivariate analysis of variance (MANOVA), with statistically significant variables computed according to Tukey's HSD test, at a confidence level of 95\% $(\mathrm{P}<0.05)$, using Statistical Analysis System (SAS) version 9.1 (SAS, 2004).

\section{RESULTS}

The two cultivars showed callus formation within 14 days (Fig. 2A and B). The highest frequency of callus induction using 2,4-D (98.59\%) for KMM was achieved following culture of stem explants on media supplemented with $4 \mathrm{mg} \mathrm{l}^{-1}$ of the auxin. The lowest was recorded using ILL on media with $10 \mathrm{mg} \mathrm{l}^{-1}$ 2,4-D (Table 2). The model cultivar

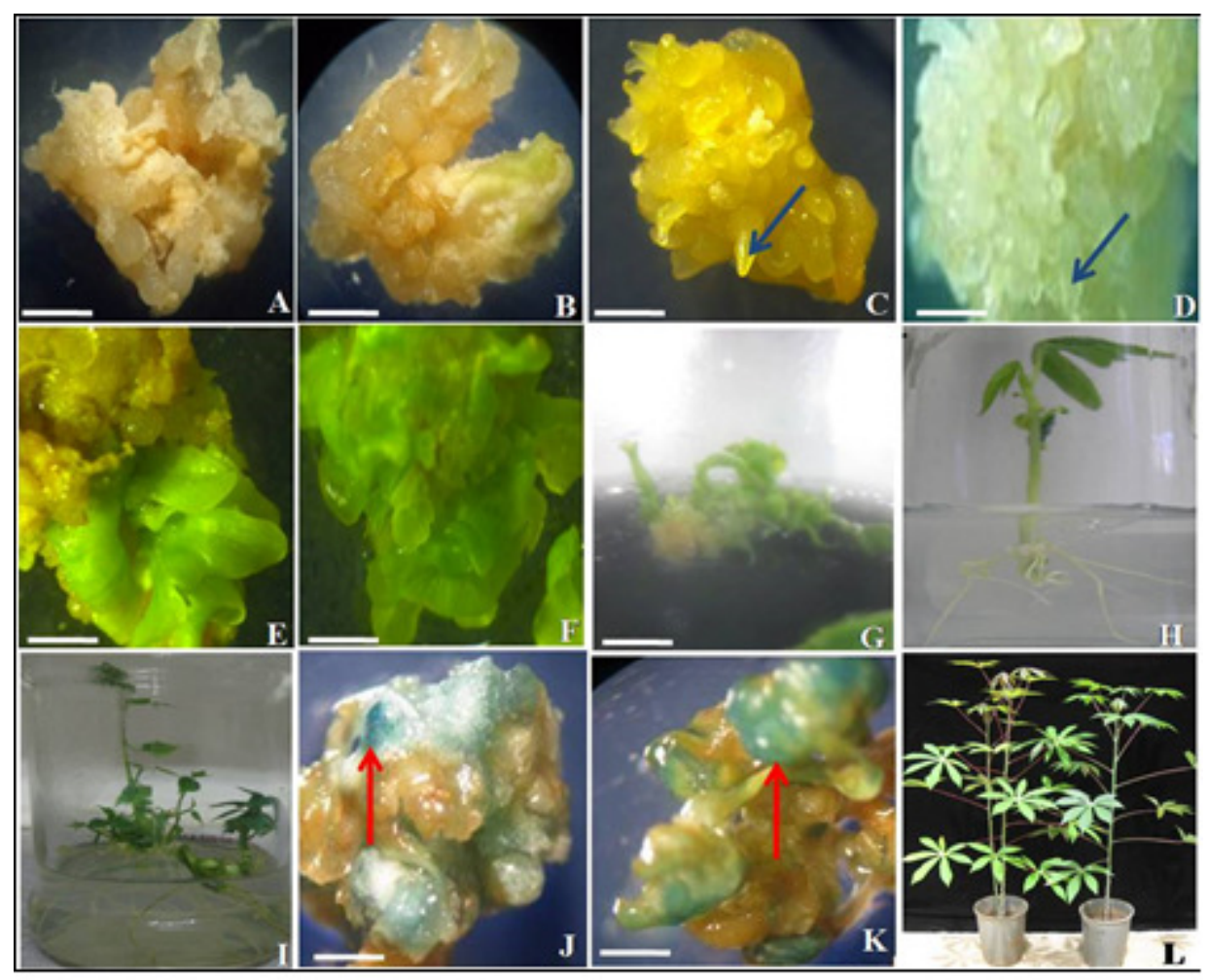

Figure 2. Callus induction, somatic embryogenesis and transformation profiles. A. Callus development in cultivar KMM. B. Appearance of callus from model cultivar TMS 60444 after 3 weeks of culture on callus induction media. C. Immature somatic embryos from cultivar KMM (indicated by the arrow) D. Cultivar TMS 60444 on immature somatic embryos CIM media. E and F Green cotyledons in KMM and TMS 60444 respectively on callus maturation media. G. Germination of mature somatic embryos on media supplemented with activated charcoal. Shoot elongation and rooting in TMS 60444 (H) and KMM (I). J. GUS assay staining of KMM and K for TMS 60444. L. Fully developed regenerants in the glasshouse Scale bar represents $0.1 \mathrm{~mm}$. 
recorded a callus induction frequency of $(98.37 \%)$ under this auxin. When explants were cultured on media with Picloram, the highest frequency of callus induction was observed in ILL (88.97\%). Relatively higher frequencies of callus induction were recorded in model cultivar TMS 60444 under similar conditions (Table 3). Calli for TMS 60444 developed faster into somatic embryos (SE) (after five weeks) compared to KMM which required seven weeks to obtain high quality primary SE (Fig. 1C and D).

The frequencies of somatic embryo formation are presented in Figure 3. Somatic embryos resulted in green cotyledons (Figs. 2E and F) for both cultivars, albeit at varying frequencies. Cotyledons were observed in both cultivars, under all maturation media formulations.

The frequencies of maturing somatic embryos across the media formulations are shown in Figure 4. The matured somatic embryos (cotyledonary embryos) later germinated on media with activated charcoal. Interestingly, KMM produced a slightly higher frequency of cotyledons than the model cultivar (Table 4).

Shoots obtained from cotyledons were successfully recovered on medium supplemented with activated charcoal (Fig. 2G). The efficiencies of shoot formation for KMM and TMS 60444 are shown in Table 4. For TMS 60444, 11 out of the 39 cotyledons $(28 \%)$ formed shoots. A slightly lower frequency of shooting (19\%) was achieved in KMM. Relatively high frequencies of transformation were recorded for both cultivars according to the Gus assay result (Figs. $2 \mathrm{~J}$ and $\mathrm{K})$. Here, the highest frequency of tissues, showing a blue coloration after Gus staining (75.3\%), was produced by the model cultivar TMS 60444; while KMM produced the lowest frequency $(60.5 \%)$ (Table 4$)$. The regenerated cassava plants grew normally in soil (Fig. 2 L).

TABLE 2. Callus induction frequency (\%) of two types of explants of two cassava cultivars cultured on MS basal medium supplemented with different concentrations of 2,4-D

\begin{tabular}{lccccc}
\hline \multirow{2}{*}{$2,4-\mathrm{D} \mathrm{conc}^{*}\left(\mathrm{mg} \mathrm{I}^{-1}\right)$} & \multicolumn{2}{c}{ Kibanda meno mkubwa } & & \multicolumn{2}{c}{ TMS 60444 } \\
\cline { 2 - 3 } \cline { 5 - 6 } & Immature leaf lobes & Stem & & Immature leaf lobes & Stems \\
\hline 4 & $82.26 \pm 0.58^{\mathrm{b}^{\mathrm{a}}}$ & $98.59 \pm 1.15^{\mathrm{a}}$ & & $91.25 \pm 1.00^{\mathrm{ab}}$ & $98.37 \pm 0.58^{\mathrm{a}}$ \\
6 & $92.11 \pm 0.58^{\mathrm{a}}$ & $92.06 \pm 1.15^{\mathrm{a}}$ & & $86.12 \pm 3.06^{\mathrm{bc}}$ & $80.05 \pm 1.73^{\mathrm{c}}$ \\
8 & $85.32 \pm 1.15^{\mathrm{b}}$ & $94.17 \pm 2.88^{\mathrm{a}}$ & & $84.20 \pm 1.73^{\mathrm{bc}}$ & $96.72 \pm 2.31^{\mathrm{a}}$ \\
10 & $74.00 \pm 1.15^{\mathrm{c}}$ & $80.38 \pm 1.15 \mathrm{~b}^{\mathrm{c}}$ & & $82.00 \pm 0.58^{\mathrm{c}}$ & $96.41 \pm 0.58^{\mathrm{a}}$ \\
\hline
\end{tabular}

*Values in the same column followed by the same letter are not significantly different $(P<0.05, n=50)$. Means separated by Turkey's HDS test at $P<0.05$

TABLE 3. Callus induction frequency (\%) of two types of explants of two cassava cultivars cultured on MS basal medium supplemented with different concentrations of Picloram

\begin{tabular}{lccccc}
\hline \multirow{2}{*}{ Picloram conc. $\left(\mathrm{mg} \mathrm{l}^{-1}\right)$} & \multicolumn{2}{c}{ Kibanda meno mkubwa } & & \multicolumn{2}{c}{ TMS 60444 } \\
\cline { 2 - 3 } \cline { 5 - 6 } & Immature leaf lobes & Stems & & Immature leaf lobes & Stems \\
\hline 4 & $65.33 \pm 1.16^{\mathrm{d}^{\mathrm{d}}}$ & $80.20 \pm 1.16^{\mathrm{b}}$ & & $70.67 \pm 1.15^{\mathrm{f}}$ & $92.49 \pm 1.73^{\mathrm{ab}}$ \\
6 & $32.31 \pm 1.17^{\mathrm{c}}$ & $84.33 \pm 1.73^{\mathrm{ab}}$ & & $48.33 \pm 2.31^{\mathrm{b}}$ & $99.31 \pm 2.31^{\mathrm{a}}$ \\
8 & $44.14 \pm 1.73^{\mathrm{d}}$ & $68.19 \pm 1.73^{\mathrm{c}}$ & & $55.67 \pm 1.15^{\mathrm{d}}$ & $81.11 \pm 1.15^{\mathrm{cd}}$ \\
10 & $88.97 \pm 1.73^{\mathrm{a}}$ & $82.02 \pm 1.73^{\mathrm{b}}$ & & $99.00 \pm 1.73^{\mathrm{a}}$ & $88.33 \pm 1.15^{\mathrm{bc}}$ \\
\hline
\end{tabular}

*Values in the same column followed by the same letter are not significantly different $(P<0.05)$. Means separated by Turkey's HDS test at $\mathrm{P}<0.05$ 


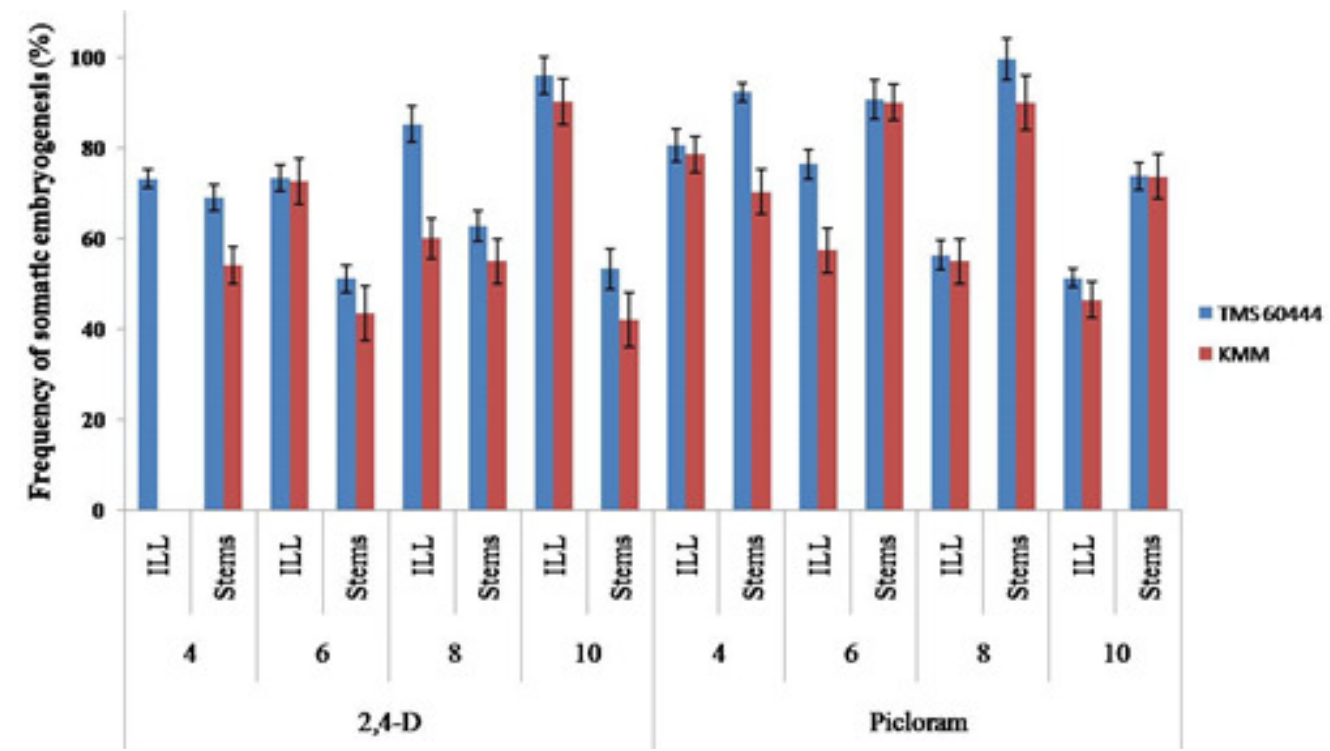

Figure 3. Effect of varying concentrations of 2,4-D/Picloram and explant types on frequency of somatic embryogenesis in a Kenyan cassava cultivar under a 16 hour light and 8 hour darkness photoperiod regime. Error bars represent standard errors of the mean $(P<0.05)$.

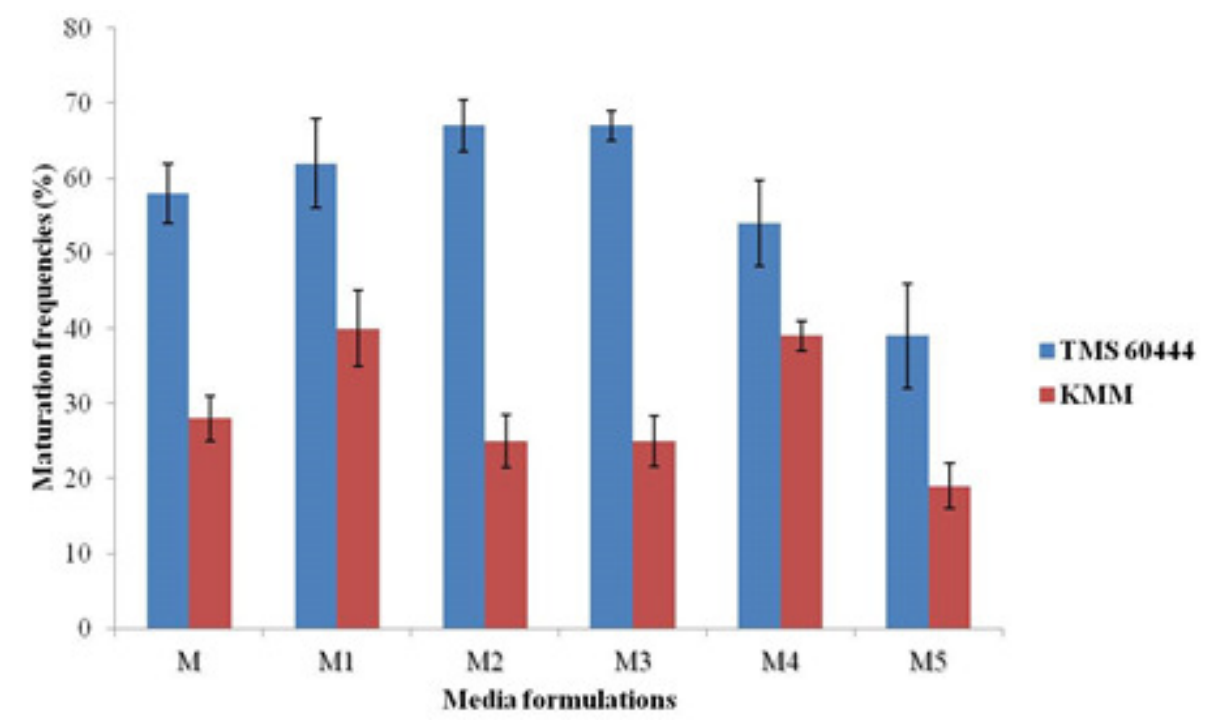

Figure 4. Effect of phyto-hormone combination ratios on frequency of maturation of somatic embryos from immature leaf lobes of Kibanda meno mkubwa (Kenya cassava cultivar) alongside TMS 60444. Error bars represent standard errors of the mean at $(\mathrm{P}<0.05)$.

\section{DISCUSSION}

Success was achieved in transforming and regenerating a farmer-preferred Kenyan cassava cultivar Kibanda meno mkubwa (KMM) (Fig. 2).
Results on callus induction and somatic embryogenesis indicate that formation of callus in cultivar KMM varies with the type and concentration of auxins used, which is in line with findings of other studies. For instance, Rossin 
TABLE 4. Somatic embryo germination, shooting and transformation frequencies of Kibanda meno mkubwa along side TMS 60444

\begin{tabular}{lccc}
\hline Cultivar & $\begin{array}{c}\text { Number of } \\
\text { germinating cotyledons }\end{array}$ & $\begin{array}{c}\text { Shooting } \\
\text { frequency (\%) }\end{array}$ & $\begin{array}{c}\text { Transient transformation } \\
\text { frequency (\%) }\end{array}$ \\
\hline Kibanda meno Mkubwa & 42 & $19.23 \pm 3.12$ & $60.15 \pm 2.33$ \\
TMS 60444 & 39 & $28.13 \pm 2.33$ & $75.33 \pm 3.45$ \\
\hline
\end{tabular}

and Rey (2011) reported similar findings in a range of cassava cultivars, where Picloram was superior to 2,4-D in generation of somatic embryos. Similarly, Saelim et al. (2006) found 2,4-D to be a superior auxin to Picloram while comparing somatic embryogenesis using different explants in the Asian cultivar KU50.

Recalcitrance of cassava to transformation and regeneration is one of the greatest challenges facing genetic modification of this crop due to the difficulties encountered in recovering whole plants following transformation (Li et al., 1998). It is, therefore, imperative that protocols for each cultivar be optimised so as to allow for a more reliable system of cassava improvement. This study achieved in regeneration and transformation of KMM, which provides a platform for cassava genetic improvement programmes.

Primary somatic embryos (SE) were observed after five weeks for TMS 60444 (Fig. 3), while it took KMM explants a further two weeks to obtain high quality SE. Combining auxins and cytokinins, during somatic embryo maturation, is essential during cassava regeneration, as these mediate whole plant recovery (Hankoua et al., 2005; 2006; Medina et al., 2007). For instance, Fan et al. (2011) demonstrated that NAA regulated organ growth; while BA facilitated cell division and elongation in cassava tuberisation. A key factor in the use of these phytohormones, is their synergistic interaction in culture media at appropriate concentrations, which ensures optimal efficiencies of regeneration. In the present study, optimisation of these phytohormones through variation of concentrations in the maturation medium, was key in ensuring growth. Here, medium M3 comprising $2 \mathrm{mg} \mathrm{l}^{-1} \mathrm{BAP}$ in combination with $0.01 \mathrm{mg} \mathrm{l}^{-1} \mathrm{NAA}$ and $1.5 \mathrm{mg} \mathrm{l}^{-1}$
$\mathrm{GA}_{3}$, was the best for maturation of somatic embryos.

The varying trend in findings observed using ILL and stem explants (Figs. 3 and 4) was as a result of genotype-explant-phytohormone interactions. In general, it was observed that somatic embryo cultures from both cultivars, induced using ILL and transferred onto maturation medium comprising $1 \mathrm{mg} \mathrm{L}^{-1} \mathrm{BAP}, 0.03$ $\mathrm{mg} \mathrm{L}^{-1} \mathrm{NAA}$ and $1 \mathrm{mg} \mathrm{L}^{-1} \mathrm{GA}_{3}$, matured and formed cotyledons albeit with varying frequencies (Fig. 4). Despite the high number of somatic embryos obtained from stem explants (Fig. 3), none of these matured into cotyledonary embryos and, hence, no plants were recovered from them. This could be as a result of differences in the pathways of somatic embryogenesis and organogenesis as revealed by Hankoua et al. (2006).

Activated charcoal was vital in plant recovery in this study, just like in other plant tissue culture efforts where it has been used to improve cell growth and development (Teixeria et al., 1994; Pan and Van Staden, 1998). The use of activated charcoal is based on its ability to adsorb inhibitory chemical compounds, mainly phenols (Liu, 1993; Teixeria et al., 1994). Cassava has been shown to produce these compounds, including coniferaldehyde and isovanillin, which are toxic, and, therefore, eliminating them from culture media is imperative for somatic embryogenesis and regeneration (Taylor et al., 2001).

Activated charcoal provides a dark environment in medium, thus promoting soil-like conditions. Thomas (2008) suggested the gradual release of adsorbed products such as nutrients and PGRs in culture media, in addition to substances naturally present in activated charcoal that promote plant growth. Transformed calli 
showed a moderate blue colouration, which is an indication that these tissues had picked up the construct during transformation.

Data on transient expression of GUS reporter gene revealed differences in frequencies of transformation between KMM and the model cultivar TMS 60444 (Fig. 2, Table 4). This shows that cassava transformation remains genotype dependent, and variability in transformation efficiencies between independent procedures cannot be totally eliminated as previously reported (Koehorst-van Putten et al., 2012).

\section{CONCLUSION}

A reproducible in vitro protocol for regeneration of a Kenyan cassava cultivar Kibanda meno mkubwa has been successful using immature leaf lobe and stem explants. This sets up a platform for further studies on this cultivar, aimed at countering the various production constraints that the crop suffers such as Cassava Mosaic and Cassava Brown Streak diseases. Of the two explants evaluated, immature leaf lobes showed better response to callus induction, somatic embryogenesis and regeneration; therefore are the best explants for regeneration of these cultivars via somatic embryogenesis. This study has also demonstrated that the cassava cultivar is transformable through Agrobacteriummediated gene transfer. The protocol for callus induction, somatic embryogenesis and whole plant recovery optimised in this study, is suitable for regenerating $\mathrm{KMM}$ and therefore is recommended. Using the best performing plant growth regulators and their combinations, as discussed above, it will be easy to regenerate this cultivar during any improvement programme, so long as the appropriate explants are selected and the ideal photoperiodic regime is followed. Further molecular work is needed to ascertain stability of the transgene in transgenic plants. Studies such as southern blot and reverse transcriptase polymerase chain reaction are recommended.

\section{ACKNOWLEDGEMENT}

The authors are grateful to the Eastern Africa Agricultural Productivity Project (EAAPP) for providing research funds and the Department of Biochemistry and Biotechnology of Kenyatta University for the facilities used for experimental work. Technical guidance from the EAAPP National Coordination Unit in Kenya and the Regional Centres of Excellence for Dairy and Cassava is highly appreciated. The Association for Strengthening Agricultural Research in Eastern and Central Africa (ASARECA) facilitated the publication of this paper.

\section{REFERENCES}

Atehnkeng, J., Adetimirin, V.O. and Ng, S.Y.C. 2006. Exploring the African cassava (Manihot esculenta Crantz) germplasm for somatic embryogenic competence. African Journal of Biotechnology 5: 1324-1329.

Ceballos, H., Iglesias, C.A., Pérez, J.C. and Dixon, A.G.O. 2004. Cassava breeding: opportunities and challenges. Plant Molecular Biology 56: 503-516.

Chetty, C.C., Rossin, C.B., Gruissem, W., Vanderschuren, H. and Rey, M.E. 2013. Empowering biotechnology in southern Africa: Establishment of a robust transformation platform for the production of transgenic industry-preferred cassava. New Biotechnology 30: 136-143.

Elibariki, G., Lupembe, M., Hosea, K. and Ndunguru, J. 2014. Evaluation of regeneration potentials of farmer preferred cassava (Manihot esculenta crantz) landraces to unlock cassava transformation barriers. International Journal of Agriculture and Crop Sciences 7: 560-568.

Fan, M., Liu, Z., Zhou, L., Lin, T., Liu, Y. and Luo, L. 2011. Effects of plant growth regulators and saccharide on In vitro plant and tuberous root regeneration of cassava (Manihot esculenta Crantz). Journal of Plant Growth Regulation 30: 11-19.

FAO. 2011. FAOSTAT Statistical Database, Agriculture Data. Internet address: hppt// apps.fao.org. Accessed on $17^{\text {th }}$ October 2014.

Fletcher, E.K.A., Amoako, T.N.E. and Twumasi, P. 2011. Effect of 2, 4-D, explants type and cultivar on the callogenesis expression of cassava (Manihot esculenta Crantz) in Ghana. 
African Journal of Biotechnology 10: 93969401.

Frame, B.R., Shou, H., Chikwamba, H.R.K, Zhang, Z., Xiang, C., Fonger, T.M., Pegg, S.E.K, Li, B., Nettleton, D.S, Pei, D. and Wang K. 2002. Agrobacterium tumefaciens-mediated transformation of maize embryos using a standard binary vector system. Plant Physiology 129:13-22

Gonsalves, D. 1998. Control of papaya ringspot virus in papaya: A case study. Annual Reviewson Phytopathology 36: 415-437.

Hankoua, B.B., Ng, S.Y.C., Fawole, I., PuontiKaerlas, J., Pillay, M. and Dixon, A.G.O.2005. Regeneration of a wide range of African cassava genotypes via shoot organogenesis from cotyledons of maturing somatic embryos and conformity of the field-established regenerants. Plant Cell, Tissue and Organ Culture 82: 221-231.

Hankoua, B.B., Taylor, N.J., Ng, S.Y.C., Fawole, I., Puonti-Kaerlas, J., Padmanabhan, C., Yadav, J.S., Fauquet, C.M., Dixon, A.G.O. and Fondong, V.N. 2006. Production of the first transgenic cassava in Africa via direct shoot organogenesis from friable embryogenic calli and germination of maturing somatic embryos. African Journal of Biotechnology 5: 1700-1712.

Jefferson, R.A. 1987. Assaying chimeric genes in plants: the GUS gene fusion system. Plant Molecular Biology Reports 5: 387-405.

Koehorst-van Putten, H. J. J., Sudarmonowati, E., Herman, M., Pereira-Bertram, I. J., Wolters, A. M. A., Meima, H., De Vetten, N., Raemakers, C. J. J. M. and Visser, R. G. F. 2012. Field testing and exploitation of genetically modified cassava with lowamylose or amylose-free starch in Indonesia. Transgenic Research 21:39-50.

Legg, J.P. and Raya, M.D. 1998. Survey of cassava virus diseases in Tanzania. International Journal of Pest Management 44: 17-23.

Li, H.Q., Guo, J.Y., Huang, Y.W., Liang, C.Y., Liu, H.X., Potrykus, I. and PuontiKaerlas, J. 1998. Regeneration of cassava plants via shoot organogenesis. Plant Cell Reports 17:410414.

Liu, M.C. 1993. Plant regeneration in cell suspension culture of sugarcane as affected by activated charcoal, medium composition and tissue culture. Taiwan Sugar 18-25. May - June.

Medina, R.D., Faloci, M.M., Gonzalez, A.M. and Mroginski, L.A. 2007. In vitro cultured primary roots derived from stem segments of cassava (Manihot esculenta) can behave like storage organs. Annals of Botany 99: 409-423.

Murashige, T. and Skoog, F. 1962. A revised medium for rapid growth and bioassays with tobacco tissue cultures. Plant Physiology 15: 473-497.

Mwango'mbe, A.W., Mbugua, S.K., Olubayo, F.O., Ngugi, E.K., Muinga, R.W., Munga, T.L. and Muiru, W.M. 2013. Challenges and opportunities in cassava production among the rural households in Kilifi county in the Coastal region of Kenya. Journal of Biology, Agriculture and Healthcare (3)10.

Opabode, J.T., Oyelakin, O.O., Akinyemiju, O.A. and Ingelbrecht, I.L. 2013. Primary somatic embryos from axillary meristems and immature leaf lobes of selected African cassava Varieties. British Journal of Biotechnology 3:263-273.

Pan, M.J. and Van Staden, J. 1998. The use of charcoal in in vitro culture. Plant Growth Regulation 26: 155-63.

Rossin, C.B. and Rey, M.E.C. 2011. Effect of explant source and auxins on somatic embryogenesis of selected cassava (Manihot esculenta Crantz) cultivars. South African Journalof Botany 77: 59-65.

Saelim, L., Phansiri, S., Netrphan, S., Suksangpanomrung, M. and Narangajavana, J. 2006. Optimisation of in vitro cyclic somatic embryogenesis and regeneration of the Asian cultivars of cassava (Manihotesculenta crantz) for genetic manipulation system. Global Journal ofBiotechnology and Biochemistry 1: 7-15.

SAS Institute, 2004. SAS/STAT 9.1: User's guide. SAS Publishers. Cary, North Carolina, USA.

Taylor, N.J., Masona, M.V., Carcamo, R., Ho, T., Schopke, C. and Fauquet, C.M. 2001. Production of embryogenic tissues and regeneration of transgenic plants in cassava (Manihotesculenta Crantz). Euphytica 120: 25-34. 
Teixeria, J.B., Sondahl, M.R. and Kirby, E.G. $1994 . \quad$ Vanderschuren, H., Stupak, M., Futterer, J., Somatic embryogenesis from immature inflorescences of oil palm. Plant Cell Reports 13:247-50.

Gruissem, W. and Zhang, P. 2007. Engineering resistance to geminiviruses: Review and perspectives. Plant

Thomas, T.D. 2008. The role of activated charcoal in plant tissue culture. Biotechnology Biotechnology Journal 5: 207-220 10.1111/ Advances 26:618-631. j.1467-7652. 2006.00217 